\title{
Desain Sistem Manajemen User Menggunakan Mikrotik User Manager di SMA Negeri 1 Ambarawa
}

\author{
Teguh Indra Bayu, Cristiano Crisanto Abel \\ Program Studi Teknik Informatika, Universitas Kristen Satya Wacana \\ Salatiga, Jawa-tengah, Indonesia \\ teguh.bayu@uksw.edu
}

Diterima: 27 Juli 2018 | Diperbaiki: 22 Agustus 2018 | Disetujui: 4 September 2018

\begin{abstract}
The purpose of this study is to analyze and optimize bandwidth management at SMA Negeri 1 Ambarawa, with the expectation that the distribution of bandwidth can be evenly distributed to each student by placing students according to the class so can optimize the bandwidth usage. Research methods used include the method of analysis by conducting surveys of existing systems and configuring on mikrotik by integrating queue tree and userman via user profiles hotspot inside mikrotik so that user can be managed on userman. The result of the research is the optimal management of available bandwidth so that the distribution of bandwidth can fit the needs of each students. The conclusion of this research is with the design of user management system using mikrotik user manager then the distribution of bandwidth on each student of SMA Negeri 1 Ambarawa can according to their respective class.
\end{abstract}

Intisari-Tujuan penelitian ini adalah menganalisis dan mengoptimalisasikan pengelolaan bandwidth pada SMA Negeri 1 Ambarawa, dengan harapan agar pembagian bandwidth dapat merata pada setiap siswa dengan menempatkan siswa sesuai kelas sehingga dapat mengoptimalkan penggunaan bandwidth. Metode penelitian yang digunakan meliputi metode analisis dengan melakukan survei terhadap sistem yang berjalan dan melakukan konfigurasi pada mikrotik dengan mengintegrasi queue tree dan user manager melalui user profiles hotspot didalam mikrotik agar user dapat dikelolah pada user manager. Hasil penelitian adalah optimalnya pengelolaan bandwidth yang ada sehingga pembagian bandwidth dapat sesuai dengan kebutuhan semua siswa. Kesimpulan dari penelitian ini adalah dengan dilakukannya desain sistem manajemen user menggunakan mikrotik user manager, maka pembagian bandwidth pada setiap siswa SMA Negeri 1 Ambarawa dapat sesuai kelasnya masing-masing.

Kata Kunci : User Manager, Queue Tree, Mikrotik.

\section{Pendahuluan}

Kebutuhan akses internet sangatlah berkembang, baik untuk berkomunikasi, melakukan pencarian data (browsing), men-download dan meng-upload data, mencari artikel, pengetahuan terbaru atau bahkan hanya untuk chatting, dari berbagai kebutuhan tersebut perlu adanya pembagian bandwidth. Pembagian bandwidth atau memanajemen bandwith pada setiap user adalah satu bagian yang penting untuk dilakukan bagi penyedia-penyedia layanan demi terciptannya akses yang cepat dan fleksibel agar memaksimalkan koneksi internet sesuai dengan kebutuhan di setiap bagian. Untuk itu, diperlukan suatu sistem manajemen bandwidth yang dapat membagi bandwidth secara merata pada setiap koneksi yang terhubung dan membatasi penggunaan bandwidth sesuai dengan yang telah ditentukan.

User manager merupakan fitur AAA server yang dimiliki oleh Mikrotik. Sesuai kepanjangan AAA (Authentication, Authorization dan Accounting), user manager memiliki Database yang bisa digunakan untuk melakukan autentikasi user yang login ke dalam network, memberikan kebijakan terhadap user tersebut misalnya limitasi transfer rate, dan juga perhitungan serta pembatasan quota yang dilakukan user nantinya. user manager akan memudahkan dalam pelayanan internet publik secara luas, misalnya hotspot-hotspot di cafe, mall, hotel, sekolah dan sebagainya, karena dengan menggunakan user manager cukup membuat 1 account user, dan account user tersebut bisa digunakan atau diakses dari router-router hotspot yang sudah dipasang[1].

Sekolah Menengah Atas Negeri 1 Ambarawa atau dikenal juga dengan nama SMANSAMBA, adalah salah satu SMA Negeri di Kabupaten Pringsewu. SMA ini berada di Jalan Sapuhanda No 001 Kecamatan Ambarawa, Kabupaten Pringsewu, karena tingginya kebutuhan akan informasi pada setiap aspek dan bertambahnya siswa setiap tahunnya internet menjadi salah satu fasilitas dan kebutuhan pokok bagi para guru dan siswa maka diperlukan suatu sistem manajemen bandwidth yang dapat membagi, mengatur jaringan internet agar memaksimalkan koneksi jaringan internet.

Dalam penelitian ini penulis melanjutkan jaringan internet yang sudah ada pada SMANSAMBA dengan menggunakan metode simple queue pada jaringan tersebut, metode ini dianggap kurang efektik dalam manangani bandwidth yang ada, dikarenakan pada dasarnya simple queue memiliki nilai max-limit yang statis, sehingga apabila traffic jaringan dalam keadaan tinggi ataupun traffic jaringan dalam keadaan rendah maka user akan tetap mendapat batasan bandwidth yang sama yang telah ditetapkan oleh admin jaringan, adapun user yang mendapatkan full bandwidth 
(unlimited) dalam mengakses jaringan internet. Hal ini dapat mengakibatkan terjadinya gangguan terhadap user lain ketika user tersebut melakukan pemakaian internet dengan trafik yang berat. Dengan mendesain sistem manajemen user menggunakan mikrotik user manager diharapkan agar setiap user yang melakukan koneksi dapat melakukan aktifitas secara nyaman dan mendapat bandwidth secara merata sesuai username dan password yang sudah ditentunkan, agar konektifitas user tidak terganggu oleh user lain. Metode ini menggunakan fasilitas queue tree yang dimiliki mikrotik karena queue tree memiliki nilai max-limit pada parent maupun child, dan user yang ada pada level child bisa menggunakan bandwidth jaringan secara full disaat kondisi jaringan sedang tidak sibuk dan pada saat jaringan sedang dalam kondisi sibuk, user akan mendapatkan nilai kecepatan di bawah max-limit karena bandwidth akan dibagi secara merata kepada seluruh user yang sedang online secara bersamaan dan memanfaatkan user manager mikrotik sebagai radius server dan service management Authentication, Authorization, dan Accounting (AAA), kebijakan ini dilakukan agar pemantaun jaringan secara terpusat untuk user yang ingin menggunakan resource dalam jaringan.

Kondisi jaringan internet di SMA Negeri 1 Ambarawa terdapat satu router mikrotik yang digunakan untuk jarigan Indihome $100 \mathrm{mbps}$. Internet dari modem kemudian diteruskan ke router, dari router dibagi menggunakan switch dan kemudian ke masing-masing Acces Point(AP). Konfigurasi yang akan dilakukan untuk manajemen bandwidth dengan menggunakan fitur user manager dan metode queue tree yang dimiliki mikrotik, user manager memiliki Database yang bisa digunakan untuk melakukan autentikasi dan kebijakan terhadap pengguna yang login ke dalam jaringan hotspot yang ada di SMA Negeri 1 Ambarawa dan queue tree berfungsi untuk mengelompokkan bandwidth dengan masing-masing ketentuan dan dilakukan limit bandwidth.

Pada penelitian ini penulis melakukan penelitian saat para siswa kelas 12 sedang dalam tahap ujian akhir kelulusan sehingga penggunaan bandwidth kemungkinan akan berkurang. Berdasarkan latar belakang yang ada, penelitian ini akan membuat Desain Sistem Manajemen User Menggunakan Mikrotik User Manager. Desain sistem ini diharapkan mampu memberi manfaat dan dapat memaksimalkan penggunaan bandwidth sesuai kebutuhan.

\section{LANDASAN TEORI}

Pada penelitian yang berjudul "Perbandingan Metode Simple Queues dan Queues Tree untuk Optimasi Manajemen Bandwidth Jaringan Komputer di SMIK PPKIA Pradnya Paramita Malang" peneliti membahas tentang perbandingan metode Simple Queues dan Metode Queues Tree untuk mendapatkan metode yang sesuai, agar masing-masing client bisa menggunakan internet dengan lancar, walaupun dengan jatah kapasitas bandwidth yang sama dari ISP (Internet Service Provider) [2].

Dalam penelitian yang berjudul "Implementasi Queues Tree untuk Optimalisasi Manajemen Bandwidth Pada Seven Net Semarang" membahas tentang di mana pada tempat studi kasus Seven Net Semarang tidak mempunyai pembagian bandwidth dalam jaringan internetnya, Seven Net Semarang adalah sebagai jasa penyedia internet biasa disebut warnet. Jasa yang disediakan bervariasi mulai dari browsing data hingga game online multiplayer, dari permasalahan tersebut peneliti 116 memperkenalkan router mikrotik dengan berbagai fitur salah satunya bandwidth management dengan metode queues tree sehingga pembagian bandwidth menjadi lebih merata dan adil [3].

Penelitian lain yang berjudul "Implementasi dan Analisa Per-Connection Queue (Pcq) Sebagai Kontrol Penggunaan Internet pada Laboratorium Komputer" membahas tentang per connection queue (PCQ) digunakan sebagai metode queues jaringan dengan jumlah client yang banyak, atau jaringan yang tidak dapat diperkirakan jumlah clientnya, misalnya pada sebuah Universitas yang ada jaringan wi-fi dan ada mengelola jaringan Lalu Lintas Kualitas Layanan (QoS). Tujuan utama dari metode ini adalah untuk melakukan bandwidth sharing otomatis dan merata ke multiclient. Kerja prinsip PCQ dengan menerapkan simple queue atau queue tree dimana hanya ada satu client aktif yang menggunakan bandwidth, sementara client lain berada dalam posisi idle maka client yang aktif tersebut dapat menggunakan bandwidth maksimum yang tersedia, tetapi jika client lain aktif, maka bandwidth yang maksimal dapat digunakan oleh kedua client (bandwidth atau jumlah client yang aktif) sehingga bandwidth dapat terdistribusi secara adil untuk semua client [4]

Pada penelitian yang berjudul "Manajemen Bandwidth Simple Queue dan Queue Tree pada PT.Endorsindo Makmur Selaras" peneliti membahas tentang Tujuan bagaimana menganalisis dan mengoptimalisasikan pengelolaan bandwidth pada PT.Endorsindo Makmur Selaras, dengan harapan agar pembagian bandwidth dapat merata pada setiap karyawan sehingga dapat meningkatkan kinerja karyawan dan kualitas perusahaan. Hasil penelitian adalah optimalnya pengelolaan bandwidth yang ada sehingga pembagian bandwidth dapat sesuai dengan kebutuhan setiap karyawan. Kesimpulan dari penelitian ini adalah dengan dilakukannya perbandingan bandwidth menggunakan metode simple queue dengan queue tree, maka pembagian bandwidth pada setiap pengguna dapat sesuai dengan kebutuhannya sehingga akses ke internet tidak terhambat[5].

Pada penelitian yang berjudul "Analisa Bandwidth Menggunakan Metode Antrian Per Connection Queue" mebahas tentang cara identifikasi lalu lintas data melalui jaringan, kemudian menerapkan kebijakan $Q o S$ yang digunakan untuk melindungi dan memprioritaskannya. Tujuan yang hendak dicapai oleh penulis adalah menyeimbangkan alokasi bandwidth sesuai untuk kebutuhan user, menerapkan aturan antrian pada lalu lintas data agar tidak terjadi antrian. Metode antrian yang digunakan dalam penelitian ini yaitu menggunakan metode Per Connection Queue dan winbox sebagai software untuk remote router[6].

Berdasarkan penelitian-penelitian yang pernah dilakukan terkait tentang perancangan manajemen bandwidth, perbandigan metode queue tree dan simple quee dan $P C Q$, maka akan dilakukan penelitian yang membahas tentang Desain Sistem Manajemen User Menggunakan Mikrotik User Manager di SMA Negeri 1 Ambarawa. Perancangan sistem manajemen user ini diharapkan agar dapat memaksimalkan bandwidth yang ada di SMA 1 Negeri Ambarawa dengan menambahkan userman pada mikrotik untuk dapat mengelolah setiap user yang terkoneksi pada jaringan hotspot khususnya para siswa SMA Negeri 1 Ambarawa. 


\section{Metodolgi Peneltitin}

Tahapan penelitian yang digunakan dalam membuat desain sistem manajemen user menggunakan mikrotik user manager di SMA Negeri 1 Ambarawa, dapat dilihat pada gambar 1. Tahapan penelitian yang ada pada Gambar 1, dijelaskan sebagai berikut: Identifikasi Masalah pada tahap ini dilakukan terhadap permasalahan yang terkait dengan membuat desain sistem manajemen user menggunakan mikrotik user manager dengan membuat menajemen bandwidth sebesar 100MB Download dan 30MB Upload, dengan besarnya bandwidth tersebut diharapkan dapat menangani konektivitas para siswa mulai dari kelas 10, 11 dan 12.

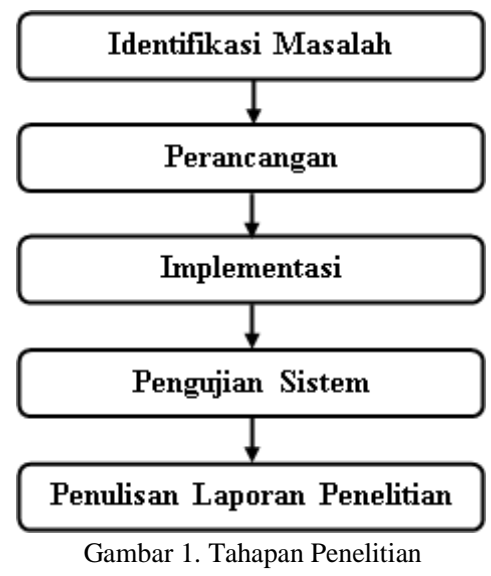

Langkah kedua dari tahapan penelitian adalah perancangan : pada tahap ini dilakukan desain dan perancangan metode queue tree pada mikrotik yang dibagi ke beberapa bagian sesuai kelas siswa.

TABEL I RanCANGAN Metode Queue TreE

\begin{tabular}{|c|c|c|c|c|c|}
\hline \multicolumn{2}{|c|}{$\begin{array}{c}\text { Total Bandwidth } \\
\text { (Global) }\end{array}$} & \multicolumn{2}{c|}{ Download } & \multicolumn{2}{c|}{ Upload } \\
\cline { 3 - 6 } & Nama & $\begin{array}{c}\text { Max } \\
\text { Limit }\end{array}$ & $\begin{array}{c}\text { Limit } \\
\text { At }\end{array}$ & $\begin{array}{c}\text { Max } \\
\text { Limit }\end{array}$ & $\begin{array}{c}\text { Limit } \\
\text { At }\end{array}$ \\
\hline 1 & SiswaKelas10 & $35 \mathrm{M}$ & $1 \mathrm{M}$ & $10 \mathrm{M}$ & $1 \mathrm{M}$ \\
\hline 2 & SiswaKelas11 & $35 \mathrm{M}$ & $1 \mathrm{M}$ & $10 \mathrm{M}$ & $1 \mathrm{M}$ \\
\hline 3 & SiswaKelas12 & $30 \mathrm{M}$ & $1 \mathrm{M}$ & $10 \mathrm{M}$ & $1 \mathrm{M}$ \\
\hline
\end{tabular}

Dapat dilihat pada tabel 1 adalah rancangan untuk metode queue tree yang dikelompokkan menjadi tiga bagian dengan memisahkan antara siswa kelas 10, 11 dan 12 dengan bandwidth download dan upload dikarenakan banyaknya kebutuhan bandwidth yang akan digunakan agar dapat meringankan penggunaan bandwidth secara bersamaan, metode ini juga diintegrasikan dengan userman untuk mengelolah pengguna atau user yang terkoneksi dalam jaringan hotspot. Terdapat juga perbedaan download dan upload untuk setiap kelas, terlihat pada tabel 1 nomor 1,2 dan 3, pada bagian Download, Limit At sebesar 1M dan Max Limit 35M. Limit At $1 \mathrm{M}$ artinya jika jaringan internet sibuk atau karena banyaknya penggunaan internet, maka yang akan didapat setiap user adalah 1M download sedangkan untuk Max Limit 35M adalah besarnya bandwidth yang didapat, ketika hanya satu user yang terkoneksi pada jaringan maka user tersebut akan mendapatkan full bandwidth, jka ada dua user maka 35M akan dibagi dua, jika seratus user maka 35M akan dibagi seratus dan seterusnya, penjelasan ini juga berlaku untuk pembagian Upload. Setelah rancangan untuk metode queue tree maka dilakukan juga rancagan terhadap profiles dan limitations untuk semua siswa sesuai kelasnya pada userman. Untuk perancangan limitations diperlukan sebuah group name yang berfungsi untuk mengintegrasi queue tree dan userman. Limitations pada userman hanya berfungsi untuk menampung nama group name karena pembagian bandwidth sudah dilakukan pada metode queue tree dengan ketentuan bandwidth yang ada, maka ketika user melakukan konektivitas atau login pada hotspot, userman akan melalukan autentikasi terhadap user tersebut dan mengidentifikasi user apakah valid atau tidak valid dan kemudian dialihkan ke queue tree untuk di limit bandwidth. Dari rancangan yang ada kemudian dibuat flowchart untuk menggambarkan logika apabila user login.

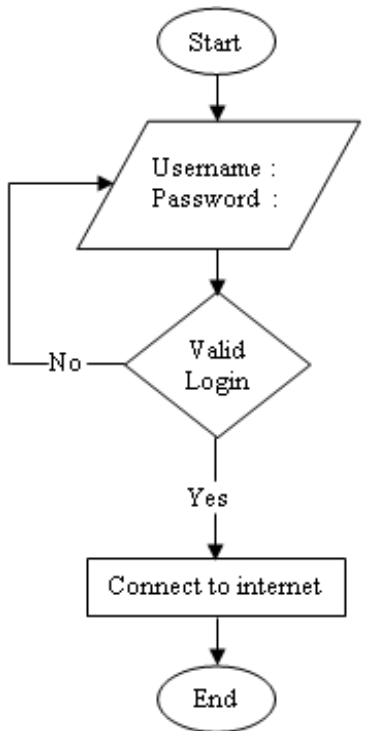

Gambar 2. Flowchart user login

Pada gambar 2 dapat dilihat bahwa apabila ada user login maka akan di proses mulai dari account user manager apakah valid atau tidak, jika valid maka user tersebut dapat melakukan koneksi internet, jika tidak maka akan kembali ke halaman login.

RouterOS yang digunakan dalam perancangan adalah RouterOS License level 6 merupakan sistem operasi mikrotik level tertinggi. Sistem operasi ini dapat menampung unlimited user, untuk jumlah user online dalam waktu bersamaan lebih dari 50 user maka diperlukan router level paling tinggi agar dapat digunakan untuk perancangan manajemen bandwidth di SMA Negeri 1 Ambarawa.

Langkah selanjutnya adalah tahap implementasi, tahap ini melakukan implementasi hasil perancangan yang telah dibuat, dengan mengkonfigurasi router mikrotik melalui winbox secara bertahap pada mikrotik, dimulai dengan menentukan IP address. IP address yang digunakan adalah 100.100.0.1/21 dikarenakan begitu banyaknya siswa SMA Negeri 1 Ambarawa yang bertambah setiap tahunnya berjumlah 1010 siswa untuk tahun ini dan juga untuk lebih awet 2 tahun kedepan, setelah itu mengkonfigurasi hotspot dengan membuat hotspot baru melalui hotspot setup pada mikrotik, agar ketika user ingin melakukan browsing internet, user akan dihadapkan kehalaman login hotspot dengan melakukan autentikasi pada username dan password, setelah hotspot dibuat maka langkah selanjutnya adalah membuat user profiles. User profiles nantinya akan berfungsi sebagai kunci untuk mengintegrasikan 
queue tree dan userman dengan menambahkan packet mark pada quеие tree dan nama user profiles pada userman, sehingga pada saat user melakukan login pada hotspot, maka userman akan mengelompokkan user melalui nama group name pada userman sesuai nama user profiles dan mengalihkan user ke queue tree melalui packet mark yang ada pada user profiles "incoming packet mark(upload) dan outgoing packet mark(Download)", user profiles dibuat sesuai perancangan dengan nama Kelas10, Kelas11 dan Kelas12. Langkah selanjutnya adalah membuat mangle untuk filtering akses (Filter Rule), Forwarding (NAT), dan juga untuk menandai koneksi maupun paket dari trafik data yang melewati router, pada pembahasan ini prerouting dan postrouting mangle diubah jump target ke hotspot sehingga pada saat user melakukan login pada hotspot maka otomatis rule mangle baru akan ditambahkan oleh user profiles. User profiles sangat berpengaruh pada queue tree dan userman. Selanjutnya konfigurasi pada implementasi queue tree, perancangan queue tree dibuat sesuai kelas siswa SMA Negeri 1 Ambarawa yaitu SiswaKelas10, SiswaKelas11 dan SiswaKelas12 bertujuan untuk memberi ruang dan jalur akses pada masing-masing kelas, dengan memanfaatkan packet mark pada user profiles sesuai packet mark "incoming packet mark (upload) dan outgoing packet mark (Download)" pada queue tree.

Tahap terakhir pada implementasi adalah membuat profiles dan limitatios pada userman dengan tujuan untuk mengintegrasikan antara userman dan queue tree, untuk itu bagian limitations userman diperlukan sebuah group name agar user dapat diahlikan ke queue tre, fungsi dari limitations menampung nama user profiles. Dalam implementasi ini dibuat tiga limitations dengan nama SiswaKelas10, SiswaKelas11 dan SiswaKelas12 dengan menambahkan nama group name sesusai nama user profiles yaitu Kelas10, Kelas11 dan Kelas12. Agar limitations terbaca dibuatlah profiles untuk setiap limitations, agar pada penemabahan user baru, user dapat diahlikan sesuai kelasnya melalui nama profiles yang telah dibuat.

Pengujian sistem, tahap pengujian dilakukan untuk mengetahui apakah hasil dari perancagan sistem manajemen user menggunakan user manager mikrotik sudah berjalan sesuai perancangan dengan baik dan apakah sistem manajemen ini dapat memberi manfaat bagi siswa.

Tahap akhir dari penelitian ini yaitu menulis laporan mulai dari tahap awal sampai tahap terakhir desain sistem manajemen user dengan mikrotik.

\section{PEMBahasan DAN HASIL}

Pada penjelasan awal perancangan dijelaskan tentang penggabungan antara userman dan queue tree. Userman dan queue tree dapat berkomunikasi karena adanya suatu mekanisme yang dilakukan dengan mengintegrasikan keduanya, cara ini dilakukan agar ketika ada user yang melakukan login pada hotspot secara otomatis userman akan melakukan autentikasi terhadap user tersebut, setelah itu akan dikelompokkan dan dialihkan ke queue tree. Dari penjelasan tersebut dapat dilihat kode program 1 berikut.

Kode program 1 adalah script untuk mengelompokkan user sesuai user profiles dan memberi packet mark pada queue tree nantinya. Pada baris 1, 2 dan 3 kode program 1 berfungsi untuk membuat user profiles, terlihat pada kode program 1 pada baris 1, 2 dan 3, yang membedakan kode program 1 antara baris 1, 2 dan 3 adalah incoming-packet-mark dan outgoing-packet118 mark yang akan dimasukkan pada queue tree. Pada kode program 1 pada baris 1, 2 dan 3 name adalah nama user profiles yang nantinya akan di-input kedalam userman pada bagian Limitations, incoming-packet-mark adalah packet mark untuk Download dan outgoing-packet-mark adalah packet mark untuk Upload.

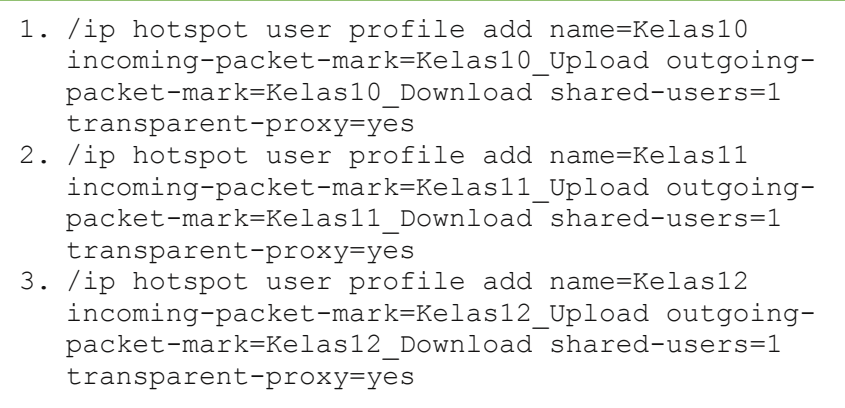

Kode Program 1. Proses Integrasi pada User Profiles

User profiles berfungsi memberi packet mark berupa incoming dan outgoing pada setiap koneksi user melalui hotspot, sehingga pada mangle untuk jump targetnya diubah ke hotspot. Setelah proses integrasi pada kode program 1 dibuat, maka akan diintegrasikan pada queue tree dengan memanfaatkan packet mark agar user dapat dikenali packet marknya dan dikelompokkan pada queue tree.

Pada kode program 2 Queue tree akan melakukan limit bandwidth sesuai yang diinput, packet mark yang digunakan pada queue tree adalah packet mark yang ada pada user profiles. Packet mark tersebut akan di tandai pada mangle dan mangle akan membuat rule baru secara otomatis ketika user melakukan login pada hotspot. Untuk bagian Download pada baris 1, 2 dan 3 kode program 2 berfungsi untuk menambahkan child queue pada parent queue Dowload dengan mengintegrasikan packet mark dari user profiles kedalam child queue, demikian juga untuk bagian Upload pada baris 1, 2 dan 3 kode program 2 berfungsi untuk menambahkan child queue pada parent queue Upload dengan mengintegrasikan packet mark dari user profiles kedalam child queue. Pada kode program 2 terlihat parent adalah nama dari parent queue Download dan parent queue Upload, packet-mark adalah inputan atau diambil dari nama packet mark yang sudah dibuat pada user profiles sebelumnya pada kode program 1 yaitu incoming-packet-mark dan outgoing-packet-mark, max-limit dan limit-at adalah batas maximum dan minimum untuk download dan upload, agar dapat menempatkan user sesuai pembagian pada quеие tree. Perbedaan kode program 2 anatara Download dan Upload baris 1, 2 dan 3 terletak pada masing-masing packet-mark untuk tiap kelas 1, 2 dan 3. 


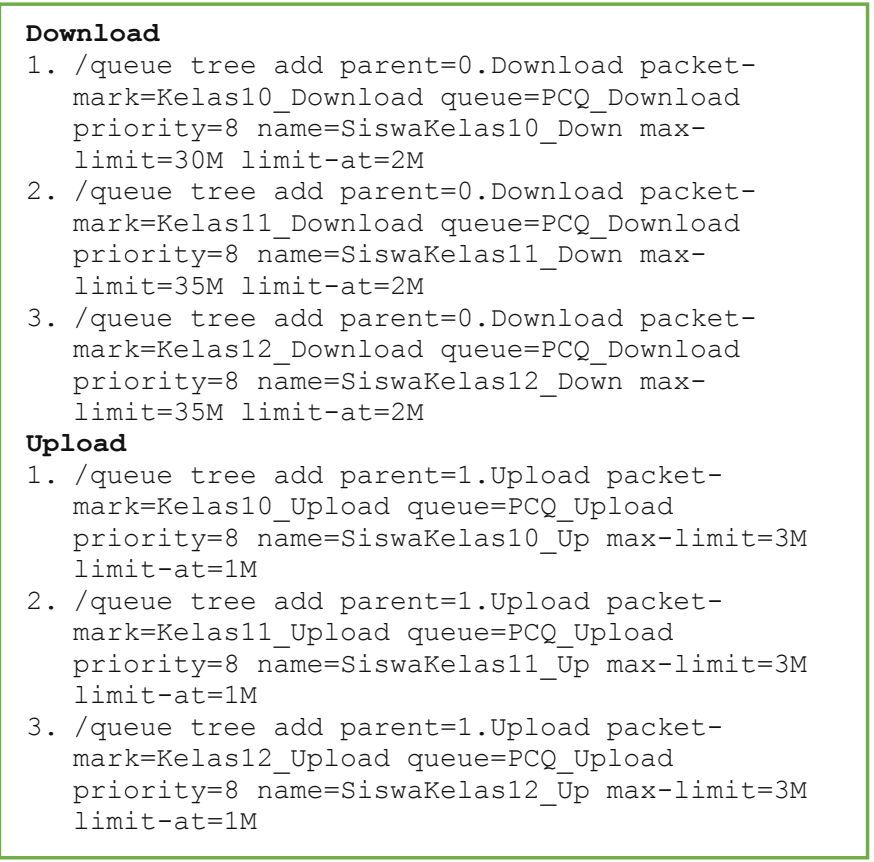

Kode Program 2. Integrasi Queue Tree dan Packet Mark

Pada kode program 2 Queue tree akan melakukan limit bandwidth sesuai yang diinput, packet mark yang digunakan pada queue tree adalah packet mark yang ada pada user profiles. Packet mark tersebut akan di tandai pada mangle dan mangle akan membuat rule baru secara otomatis ketika user melakukan login pada hotspot. Untuk bagian Download pada baris 1, 2 dan 3 kode program 2 berfungsi untuk menambahkan child queue pada parent queue Dowload dengan mengintegrasikan packet mark dari user profiles kedalam child queue, demikian juga untuk bagian Upload pada baris 1, 2 dan 3 kode program 2 berfungsi untuk menambahkan child quеие pada parent quеие Upload dengan mengintegrasikan packet mark dari user profiles kedalam child queue. Pada kode program 2 terlihat parent adalah nama dari parent queue Download dan parent qиеие Upload, packet-mark adalah inputan atau diambil dari nama packet mark yang sudah dibuat pada user profiles sebelumnya pada kode program 1 yaitu incoming-packet-mark dan outgoing-packet-mark, max-limit dan limit-at adalah batas maximum dan minimum untuk download dan upload, agar dapat menempatkan user sesuai pembagian pada quеие tree. Perbedaan kode program 2 anatara Download dan Upload baris 1, 2 dan 3 terletak pada masing-masing packet-mark untuk tiap kelas 1, 2 dan 3.

Tahap akhir pada pembahasan ini adalah mengintegrasikan userman ke dalam queue tree dengan memanfaatkan limitations dan profiles yang ada pada userman terlihat pada kode program 3 berikut.

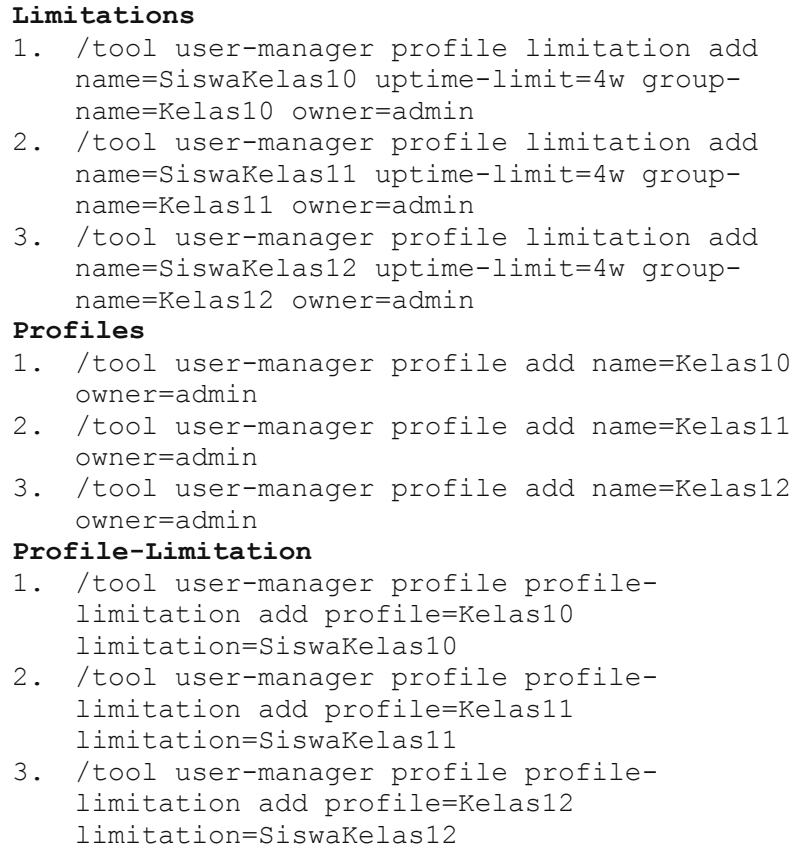

1. /tool user-manager profile add name=Kelasio owner=admin

2. /tool user-manager profile add name=Kelasil owner=admin

3. /tool user-manager profile add name=Kelas12 owner=admin

Profile-Limitation

1. /tool user-manager profile profilelimitation add profile=Kelas10

Kode Program 3. Integrasi Userman kedalam Queue Tree

Pada kode program 3 merupakan script tahap akhir proses integrasi dengan memasukan nama user profiles hotspot kedalam group name pada userman sehingga ketika user melakukan login dan user akan diahlikan ke queue tree melalui user profiles sesuai group name dan packet-mark yang terdapat pada user profiles. Pada proses limitations dan profiles user akan diproses sesuai profile masing-masing, sehingga pada saat menambahkan user akan dimasukkan kedalam salah satu profile contohnya profile kelas10, maka secara otomatis user akan diahlikan ke queue tree. Pada bagian Limitations pada baris 1, 2 dan 3 kode program 3 berfungsi untuk membuat limitation pada user dengan nama SiswaKelas 10, SiswaKelas 11 dan SiswaKelas12, limition hanya berfungsi untuk menampung nama group name karena pembagian bandwidth akan ditangani oleh queue tree, user akan dipisahkan sesuai group name pada limition, nama group name diambil dari nama user profiles pada kode program 1, perbedaan kode program 3 baris 1, 2 dan 3 bagian Limitations terletak pada group-name yang diambil dari nama user profiles kode program 1. Bagian Profiles baris 1, 2 dan 3 kode program 3 berfungsi untuk membuat profile sehingga saat menambahkan, user, user dapat memilih profile sesuai kelas siswa. Bagian Profile-Limitation baris 1, 2 dan 3 kode program 3 berfungsi untuk menambahkan atau mengaktifkan limitation pada profiles yang sudah dibuat agar ketika user melakukan login pada hotspot, userman dapat mengelompokkan user sesuai kelas siswa setelah itu akan diahlikan pada queue tree, perbedaan kode program 3 baris 1, 2 dan 3 bagian Profile-Limitation terletak pada limitation yang berfungsi untuk menempatkan user kedalam pembagian quеие tree. Setelah selesai pembahasan proses integrasi antara queue tree dan userman maka selanjutnya diperoleh hasil penggunaan selama 2 bulan dari bulan mei sampai bulan juni pada SMA Negeri 1 Ambarawa. 


\begin{tabular}{|c|c|c|c|c|}
\hline Name & Parent & Limit At (bits/s) & Max Limit (bits/s) & Bytes \\
\hline \multicolumn{5}{|c|}{ :- Total Download Untuk Semua Siswa dari Kelas 1011 dan 12} \\
\hline P0. Download & global & & $100 \mathrm{M}$ & $904.9 \mathrm{MiB}$ \\
\hline S SiswaKelas 10_Down & 0.Download & $1 \mathrm{M}$ & $35 \mathrm{M}$ & $246.5 \mathrm{MB}$ \\
\hline S SiswaKelas11_Down & 0.Download & $1 \mathrm{M}$ & $35 \mathrm{M}$ & $612.3 \mathrm{MiB}$ \\
\hline S SiswaKelas12_Down & 0.Download & $1 \mathrm{M}$ & $30 \mathrm{M}$ & $46.0 \mathrm{MBB}$ \\
\hline \multicolumn{5}{|c|}{ :-: Total Upload Untuk Semua Siswa dari Kelas 1011 dan 12} \\
\hline S1.Upload & global & & $30 \mathrm{M}$ & $463.4 \mathrm{MB}$ \\
\hline S Siswakelas 10_Up & 1.Upload & $1 \mathrm{M}$ & $10 \mathrm{M}$ & $1222 \mathrm{MiB}$ \\
\hline SiswaKelas11_Up & 1. Upload & $1 \mathrm{M}$ & $10 \mathrm{M}$ & $315.2 \mathrm{MiB}$ \\
\hline Siswakelas12_Up & 1. Upload & $1 \mathrm{M}$ & $10 \mathrm{M}$ & $26.0 \mathrm{MB}$ \\
\hline
\end{tabular}

Gambar 3. Hasil penggunaan bandwidth dalam dua bulan

Pada gambar 3 dapat dilihat hasil penggunaan bandwidth selama dua bulan, dengan mengintegrasi queue tree dan userman melalui user profiles peneliti membagi para siswa dalam tiga jalur bandwidth dengan mengelompokkan tiap kelas agar dengan bandwidth 100MB Download dan 30MB Upload ini dapat diakses bersamaan, namun dengan pembagian masingmasing bandwidth, sehingga tidak mengganggu konektivas antara kelas 10, 11 dan 12. Pada gambar 3 untuk siswa kelas 12 kurangnya penggunaan karena dalam masa ujian akhir dan dalam masa kelulusan.

\section{SIMPULAN}

Berdasarkan hasil pengujian dan pembahasan dapat disimpulkan bahwa: Userman dan Queue Tree dapat diintegrasikan didalam Mikrotik dengan memanfaatkan packet mark yang pada User Profiles. Queue Tree berjalan semestinya dengan membagi dan mengelompokkan para siswa sesuai kelasnya masing-masing, dan pada kasus SMA Negeri 1 Ambarawa terdapat kelompok, yaitu kelas 12 yang sedang menjalani ujian sekolah, dan alokasi bandwidth yang tidak digunakan oleh kelas 12, dapat digunakan oleh kelompok kelas lain (10 dan 11).

Pada penelitian ini tidak terlepas dari kekurangan yang kemungkinan dapat disempurnakan pada penelitian lain, ada beberapa saran yang bisa dijadikan sebagai tambahan lain pada penelitian berikutnya seperti dalam melakukan pembagian bandwidth langsung pada setiap user.

\section{REFERENCES}

[1] Mikrotik.id., 2005, “Integrasi Hotspot dengan User Manager," http://www.mikrotik.co.id/artikel_lihat.php?id=46, Diakses 12 April 2018.

[2] Syaifuddin. Aris, Yunus. Mahmud, dan Sundari. Retno, "Perbandingan Metode Simple Queues dan Queues Tree untuk Optimasi Manajemen Bandwidth Jaringan Komputer (Studi Kasus: Stmik Ppkia Pradnya Paramita Malang)," Jurnal Teknik Informatika dan Sistem Informasi (STMIK PPKIA), Vol. 4 No. 2, 2010.

[3] Gunawan. Bagus Akhmad, "Implementasi Queue Tree untuk Optimalisasi Manajemen Bandwidth (studi Kasus: Pada Seven Net Semarang)," Artikel Teknik Informatika (Universitas Dian Nuswantoro), 2014.

[4] Mirsantoso. Kalsum, Toibah. Umi, dan Supardi. Reno, "Implementasi dan Analisa Per-Connection Queue (Pcq) Sebagai Kontrol Penggunaan Internet (Studi kasus: Laboratorium Komputer)," Jurnal Media Infotama (Universitas Dehasen Bengkulu), Vol. 11 No. 2, 2015.

[5] Budiman. Arif, "Manajemen Bandwidth Simple Queue dan Queue Tree (Studi kasus: PT. Endorsindo Makmur Selaras)," Jurnal Penelitian Ilmu Komputer, System Embedded \& Logic 3(1):11-27, 2015.

[6] Sukri dan Jumiati, "Analisa Bandwidth Menggunakan Metode Antrian Per-Connection Queue," (Jurnal Teknologi dan Sistem Informasi Univrab VOL. 2 No. 2, Juli 2017. 